\title{
EFEK ANTIMITOSIS EKSTRAK BAWANG DAYAK (Eleutherina americana L. Merr) TERHADAP SEL TELUR BULU BABI \\ (Tripneustes gratilla Linn.)
}

\author{
Ahmad Efendi, Islamudin Ahmad, Arsyik Ibrahim \\ Laboratorium Penelitian dan Pengembangan FARMAKA TROPIS Fakultas Farmasi \\ Universitas Mulawarman, Samarinda, Kalimantan Timur \\ email: kakfendi@gmail.com
}

\begin{abstract}
ABSTRAK
Bawang dayak (Eleutherina americana L. Merr) merupakan salah satu tanaman obat yang banyak digunakan oleh masyarakat sebagai obat tradisional, salah satunya adalah sebagai obat anti kanker. Penelitian ini bertujuan untuk mengetahui $\mathrm{IC}_{50}$ dari ekstrak n-heksan, etil asetat dan etanol umbi bawang dayak (Eleutherina americana L. Merr) dengan metode penghambatan mitosis zigot bulu babi (Tripneustes gratilla Linn.).Hasil uji aktivitas antimitosis menunjukkan ekstrak $n$-heksan memiliki nilai $\mathrm{IC}_{50} 16,03 \mathrm{ppm}$, sedangkan pada ekstrak etilasetat dan etanol berturut-turut adalah 2,07 ppm dan 4,67 ppm. Data hasil penelitian ini menunjukkan bahwa ekstrak etilasetat memiliki aktivitas antimitosis paling kuat dibandingkan dengan ekstrak $n$-heksan dan etanol.
\end{abstract}

Kata Kunci: Eleutherina americana L. Merr, Antimitosis, $\mathrm{IC}_{50}$

\section{PENDAHULUAN}

Bawang dayak (Eleutherine
americana (L.) Merr) merupakan tanaman khas Kalimantan Tengah. Tanaman ini sudah secara turun temurun dipergunakan masyarakat Dayak sebagai tanaman obat. Tanaman ini memiliki warna umbi merah dengan daun hijau berbentuk pita dan bunganya berwarna putih. Dalam umbi bawang dayak terkandung senyawa fitokimia yakni alkaloid, glikosida, flavonoid, fenolik, steroid dan tannin. Secara empiris bawang dayak sudah dipergunakan masyarakat lokal sebagai obat berbagai jenis penyakit seperti kanker payudara, obat penurun darah tinggi (Hipertensi), penyakit kencing manis (diabetes melitus), menurunkan kolesterol, obat bisul, kanker usus dan mencegah stroke. Penggunaan bawang dayak dapat dipergunakan dalam bentuk segar, simplisia, manisan dan dalam bentuk bubuk (powder). Potensi bawang dayak sebagai tanaman obat multi fungsi sangat besar sehingga perlu ditingkatkan penggunaanya sebagai bahan obat modern.

Penelusuran pada penentuan aktivitas antioksidan ekstrak etanol umbi bawang dayak menunjukkan aktivitas penghambatan yang kuat dengan nilai IC $_{50}$ sebesar 25,3339 ppm (Evi, 2009). Hal ini menunjukkan bahwa ekstrak etanol umbi bawang dayak (Eleutherine palmifolia (L.) Merr) memiliki potensi sitotoksik yang dapat dikembangkan sebgai bahan antikanker. Molyneux (2004) menyatakan bahwa suatu zat mempunyai sifat antimitosis bila nilai $\mathrm{IC}_{50}$ kurang dari $200 \mathrm{ppm}$. Bila nilai $\mathrm{IC}_{50}$ yang diperoleh berkisar antara 200-1000 ppm, maka zat tersebut kurang aktif namun masih berpotensi sebagai zat antimitosis. Untuk meneliti lebih lanjut potensi tersebut, ekstrak umbi bawang dayak (Eleutherine americana (L.) Merr) diuji aktivitasnya dengan metode penghambatan sel telur bulu babi (Tripneustes gratilla Linn). 
Salah satu uji yang dilakukan untuk mengidentifikasi suatu senyawa yang memiliki aktivitas sebagai antikanker adalah dengan mengetahui aktivitas senyawa tersebut dalam menghambat pertumbuhan sel (mitosis). Mitosis hanya merupakan satu bagian dari siklus sel. Sebenarnya fase mitotik (M), yang mencakup mitosis dan sitokinesis, biasanya merupakan bagian tersingkat dari siklus sel tersebut. Pembelahan sel miotik yang berurutan bergantian interfase yang jauh lebih lama, yang seringkali meliputi $90 \%$ dari siklus ini. Selama interfase inilah sel tumbuh dan menyalin kromosom dalam persiapan untuk pembelahan sel. Interfase dapat dibagi menjadi subfase : fase G1 ("gap pertama"), fase S, dan fase G2 ("gap kedua"). Selama ketiga subfase ini sel tumbuh dengan menghasilkan protein dan organel dalam sitoplasma. Kromosom diduplikasi hanya selama fase S (S singkatan untuk sintesa DNA). Dengan demikian, suatu sel tumbuh (G1), terus tumbuh begitu sel tersebut sudah menyalin kromosomnya (S), dan tumbuh lagi sampai sel tersebut menyelesaikan persiapannya untuk pembelahan sel (G2), dan membelah (M). Sel anak kemudian dapat mengulangi siklus ini (Campbell, 2004). Dalam beberapa hal, sel kanker mirip sel embrio bulu babi (Tripneustes gratilla Linn) misalnya dari proses pembelahan sel. Pada pembelahan mitosis sama sama memulai pada periode tumbuh (G1), kemudian fase S (sintesa DNA) lalu ke fase tumbuh kedua (G2) sebelum terjadi mitosis berikutnya. Hal ini, bahwa sel kanker sebagaimana sel dideferesnsiasi ialah sel kanker sering memperlihatkan protein yang khas juga terdapat pada perkembangan sel normal alfa fetoprotein (AFP) dan antigen karsinoembrio (CFA) (Campbell, 2004).

\section{METODE PENELITIAN}

\section{Bahan}

Bahan yang digunakan adalah ekstrak n-heksana, ekstrak etil asetat, dan ekstrak etanol bawang dayak; $\mathrm{KCl}$ 10\%; pelarut-pelarut organik; air laut; bulu babi (Tripneustus gratilla Linn.) diambil dari daerah Melahing Kota Bontang, Kalimantan Timur.

\section{Peralatan}

Alat yang digunakan adalah perangkat alat ekstraksi, kromatografi lapis tipis; alat-alat gelas; perangkat alat uji sitotoksik.

\section{Pengumpulan dan PenyiapanSampel}

Bawang dayak diperoleh dari Kota Samarinda, Kalimantan Timur. Bawang dayak segar dikumpulkan kemudian dilakukan sortasi basah. Setelah itu, dicuci dan dikeringkan dengan cara diangin-anginkan di dalam ruangan yang terlindung dari sinar matahari. Selanjutnya umbi bawang dayak kering dipotong kecil-kecil menjadi serbuk simplisia.

\section{Ekstraksi dan Fraksinasi}

Serbuk simplisia dimasukkan ke dalam alat soxlet menggunakan pelarutdengan kepolaran bertingkat, dari pelarut yang kurang polar hingga menggunakan pelarut dengan itngkat kepolaran yang lebih tinggi ( $n$-heksana, etil asetat, dan etanol). Proses ekstraksi dengan metode soxlet berlangsung selama kurang lebih 7-8 siklus alat soxlet. Ekstrak hasil soxlet ditampung ke dalam wadah, kemudian dipekatkan menggunakan rotary evaporator dan dilanjutkan dengan penguapan di dalam desikator hingga diperoleh ekstrak $n$ heksan, etil asetat, dan etanol kering.

\section{Pengujian Aktivitas Antimitosis}

Bulu babi jantan dan betina diinduksi dengan menyuntikkan $1 \mathrm{~mL}$ $\mathrm{KCl} 10 \%$ ke dalam rongga perivisceral, 
sperma dan ovum masing-masing ditampung dalam gelas kimia yang berbeda dan telah diisi air laut bebas. Fertilisasi dilakukan dengan cara menambahkan sperma dan sel telur ke dalam 50 mLair laut dan dibiarkan selama 5 menit sebelum digunakan. Larutan stok dibuat dengan konsentrasi 100 ppm dengan melarutkan $0,1 \mathrm{mg}$ sampel dalam $10 \mathrm{~mL}$ air laut. Dibuat seri konsentrasi uji untuk ekstrak n-heksana 10, 25, 50, dan 75 ppm, untuk ekstrak etil asetat dan etanol bawang dayak 0,5, 1, 2, 4, dan 8 ppm. Sediaan uji ini dibuat dalam $2 \mathrm{~mL}$ suspensi kedalam tabung eppendorf. Kemudian diinkubasi pada suhu kamar dengan pengocokan yang cukup sering, dan dilakukan 3 replikasi untuk masing-masing sampel uji. Embrio dibiarkan berkembang hingga ke pembelahan tahap pertama antara jam ke-2 sampai ke-3. Campuran tersebut diambil $100 \mu \mathrm{l}$ dan diamati di bawah mikroskop. Penghambatan pembelahan sel diamati dari populasi sekitar 100-480 sel telur setelah inkubasi. Kontrol negatif tanpa sampel uji dapat dianggap memiliki pertumbuhan $100 \%$. Aktivitas penghambatan pertumbuhan sel

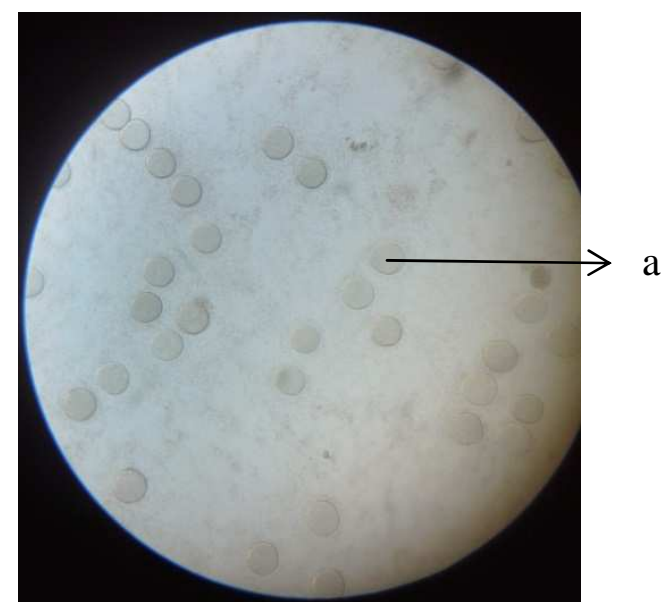

dinyatakan dengan nilai $\mathrm{IC}_{50}$.Secara spesifik, suatu senyawa dikatakan sebagai antimitosis yang sangat kuat jika nilai $\mathrm{IC}_{50}$ kurang dari 50 ppm.

\section{HASIL DAN PEMBAHASAN}

Aktivitas antimitosis ekstrak umbi bawang dayak diukur dari kemampuan ekstrak umbi bawang dayak dalam menghambat pembelahan sel telur bulu babi. Pengujian aktivitas antimitosis ekstrak umbi bawang dayak terhadap sel telur bulu babi dilakukan dengan berbagai tingkat konsentrasi. Adapun konsentrasi uji yang digunakan pada ekstrak n-heksana yaitu 10, 25, 50, dan 75 ppm, untuk konsentrasi uji yang digunakan pada ekstrak etil asetat terhadap sel telur bulu babi adalah $0,5,1$, 2, 4,dan 8 ppm. Sedangkan pada ekstrak etanol, konsentrasi uji yang digunakan yaitu $0,5,1,2,4$ dan 8 ppm. Pengujian antimitosis dilakukan sebanyak 3 kali replikasi atau pengulangan terhadap masing-masing sel telur bulu babi uji yang digunakan. Hasil pengujian dari aktivitas antimitosisekstrak bawang dayak yang dibandingkan dengan kontrol negatif dapat dilihat pada Gambar 1 .

Gambar 1. (a) Sel telur yang belum mengalami pembuahan pada menit ke-0, (b) Sel telur yang telah mengalami pembelahan menit ke-120 (terdapat inti sel dan dinding sel baru), (c) Sel telur yang mengalami penghambatan pembelahan 


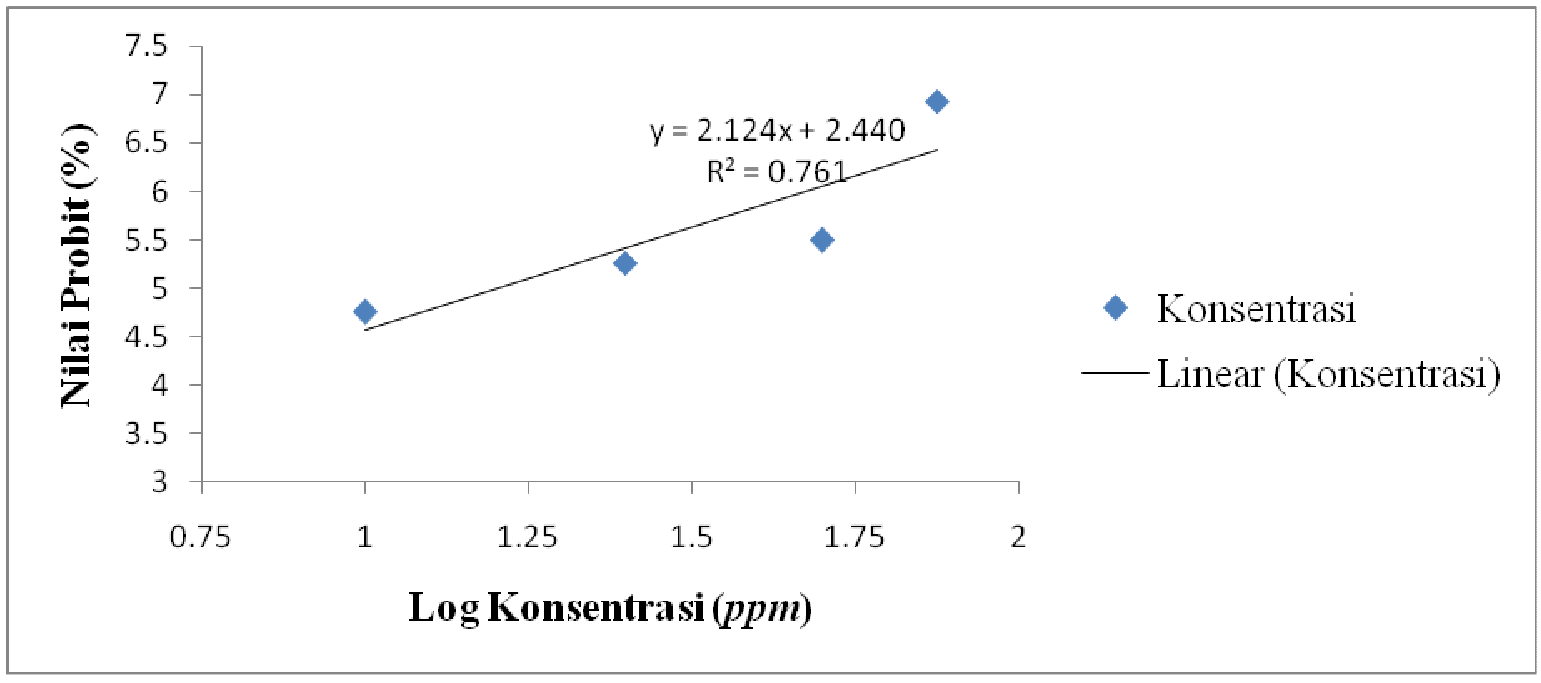

Gambar 2.Grafik Hubungan Konsentrasi dengan Persen Aktivitas Antimitosis Ekstrak nheksana Bawang Dayak

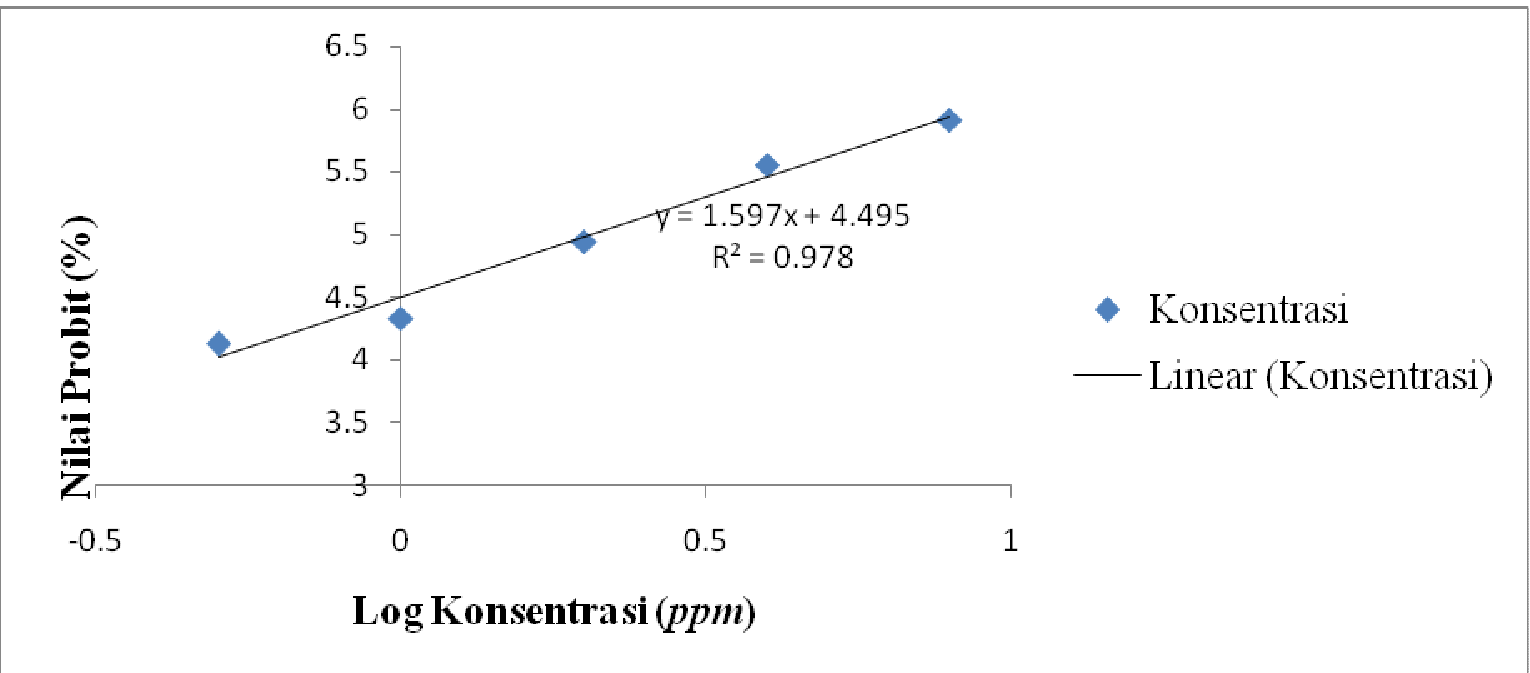

Gambar 3. Grafik Hubungan Konsentrasi Dengan Persen Aktivitas Antimitosis Ekstrak Etil Asetat Bawang Dayak

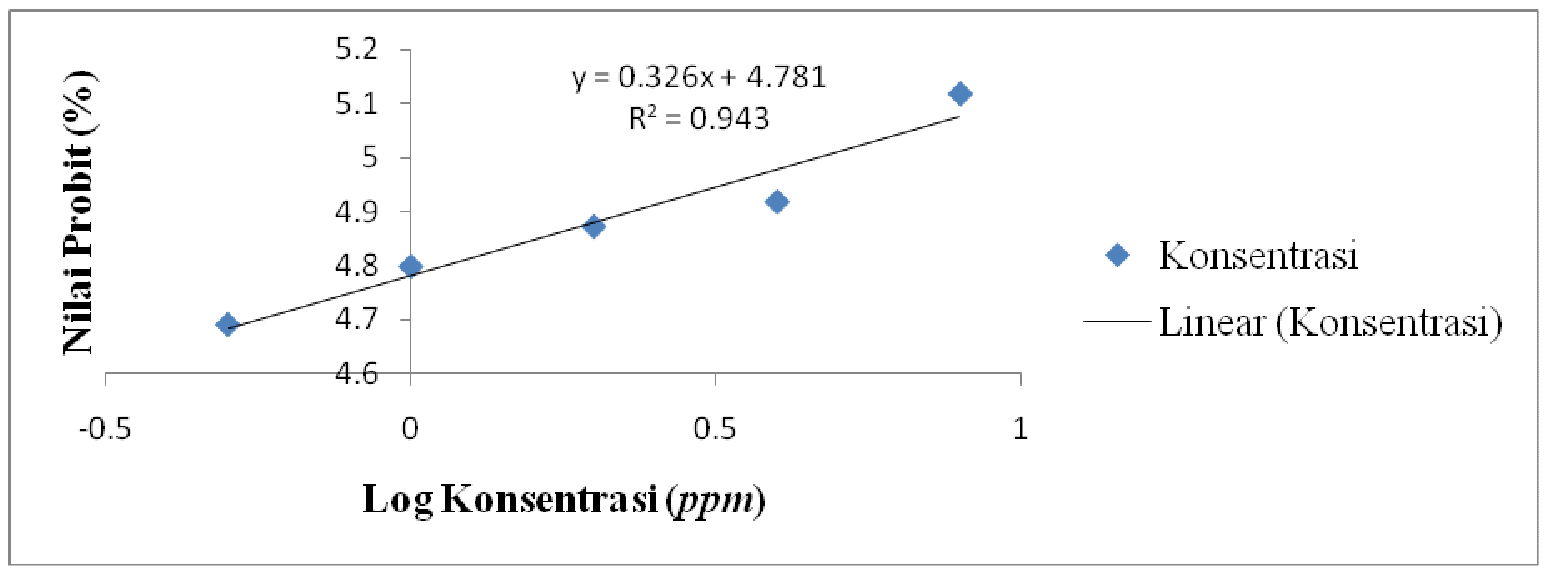

Gambar4. Grafik Hubungan Konsentrasi Dengan Persen Aktivitas Antimitosis Ekstrak Etanol Bawang Dayak 
Gambar 1 menunjukkan bahwa ekstrak umbi bawang dayak memiliki aktivitas antimitosis terhadap sel telur bulu babi yang ditandai dengan adanya penghambatan pembelahan sel telur bulu babi. Kontrol negatif sebagai pembanding yaitu air lautyang ditambahkan sel telur bulu babi tanpa penambahan ekstrak umbi bawang dayak. Dari gambar 1 juga terlihat bahwa pada uji kontrol negatif mengalami pembelahan $100 \%$ dibandingkan ekstrak $n$-heksana, etil asetat, dan etanol umbi bawang dayak. Data hasil pengukuran aktivitas antimitosis ekstrak fraksi umbi bawang dayak dapat dilihat pada Gambar 2, Gambar 3, dan Gambar 4.
Gambar 2, Gambar 3, dan Gambar 4 menunjukkan adanya aktivitas antimitosis ekstrak n-heksana, etil asetat, dan etanol bawang dayak terhadap sel telur bulu babi. Dapat dilihat aktivitas antimitosis dari ketiga ekstrak bawang dayak tersebut bahwa semakin tinggi konsentrasi ekstrak uji semakin tinggi pula aktivitas antimitosisnya. Dan ketiga ekstrak tersebut tergolong memiliki aktivitas antimitosis sangat karena nilai $\mathrm{IC}_{50}$ ekstrak berada dibawah $50 \mathrm{ppm}$.

Hasil pengukuran daya hambat pembelahan sel telur bulu babi yang terlihat pada Tabel 1 menunjukkan adanya aktivitas antimitosis pada ekstrak umbi bawang dayak terhadap sel telur bulu babi.

Tabel 1. Nilai IC 50 Bawang Dayak

\begin{tabular}{cc}
\hline Sampel Uji & $\mathrm{IC}_{50}(\mathrm{ppm})$ \\
\hline Ekstrak n-heksana & 16,03 \\
Ekstrak etil asetat & 2,07 \\
Ekstrak etanol & 4,67 \\
\hline
\end{tabular}

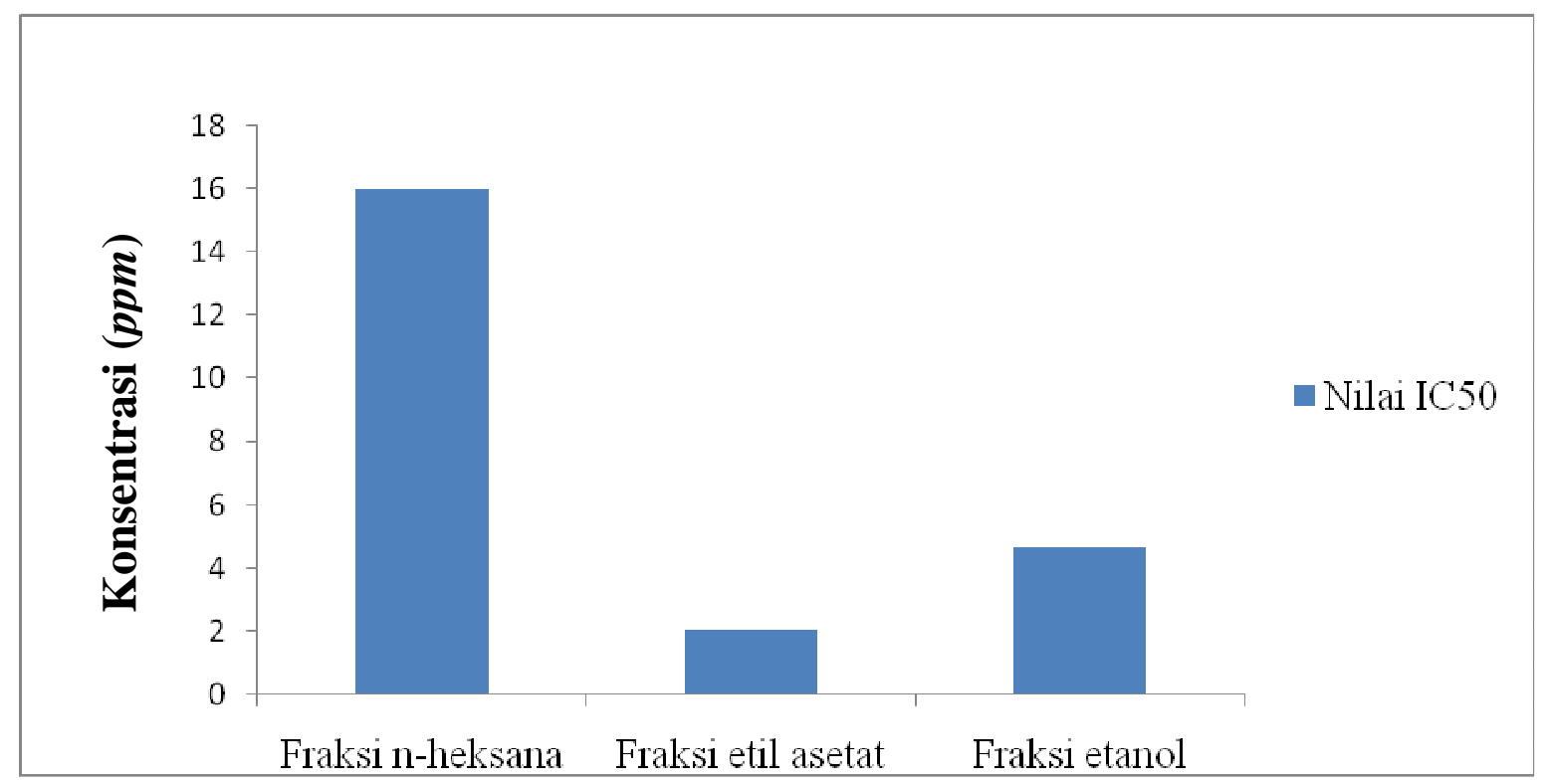

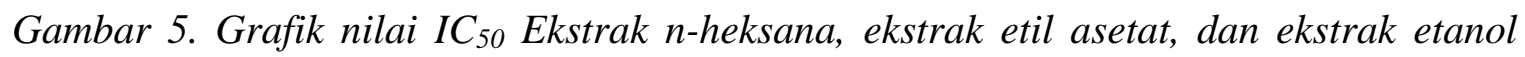
umbi bawang dayak 
Berdasarkan Gambar 5, menunjukkan bahwa semakin kecil nilai $\mathrm{IC}_{50}$ ekstrak maka semakin tinggi aktivitas antimitosisnya. Sehingga dapat disimpulkan bahwa ekstrak etil asetat bawang dayak yang memberikan aktivitas yang terbaik, Hal ini diperkirakan karena telah terjadi pengelompokan senyawa antimitosis di dalam ekstrak tersebut, sehingga aktivitasnya menjadi lebih tinggi apabila dibandingkan dengan ekstrak yang lain. Urutan ekstrak yang memberikan aktivitas antimitosis yang baik setelah ekstrak etil asetat adalah ekstraketanol dan ekstrak $n$-heksana bawang dayak.

\section{KESIMPULAN}

Ekstrak bawang dayak (Eleutherina americana L. Merr) memiliki aktivitas antimitosis terhadap sel telur bulu babi (Tripneustes gratilla Linn.), dengan nilai $\mathrm{IC}_{50}(\mathrm{ppm})$ ekstrak $n$ heksana bawang dayak 16,03 ppm, ekstrak etil asetat 2,07 ppm dan ekstrak etanol 4,08 ppm terhadap pembelahan sel telur bulu babi (Tripneustes gratilla Linn.).

\section{DAFTAR PUSTAKA}

1. Campbell, J. B. Reece, L. G dan Mitchell. 2004. Biologi. Edisi kelima. Jilid 3. Jakarta :Penerbit Erlangga.

2. Costa-Latufo, L.V., Ferreira, M.A.D., Lemos, T.L.G., Pessoa, O.D.L., Viana, G.S.B., and Cunha, G.M.A., Toxicity to sea urchin egg development of the quinone fraction obtained from Auxemmaoncocalyx, Braz J Med Biol Res, August 2002, Volume 35(8) 927-930.

3. Evi Mintowati, Maria Dewi Astuti, 2009, Penentuan Aktivitas Antioksidan Ekstrak Etanol Bawang Dayak (Eleutherine americanaMerr.),Unlam, Banjarmasin

4. Firdaus, R., 2007, Telaah Kandungan Kimia Ekstrak Metanol Umbi Bawang Dayak (Eleutherina Americana (Aubl.) Merr), (http://bahan-alam/fa.itb.ac.id), diakses 10 Januari 2013

5. Roxanne, dan Kelvin G. 2010. Sea Urchin Fertilization Lab. Hawai' $i$ Institute of Marine Biology: Hawai 